\title{
Ximelagatran reduced venous thromboembolism more than warfarin after total knee replacement
}

Francis CW, Berkowitz SD, Comp PC, et al. Comparison of ximelagatran with warfarin for the prevention of venous thromboembolism after total knee replacement. N Engl J Med 2003;349:1703-12.

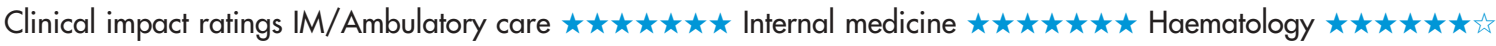

In patients having total knee replacement, is ximelagatran better than warfarin in preventing venous thromboembolism (VTE)?

\section{METHODS}

\begin{tabular}{|c|c|}
\hline & $\begin{array}{l}\text { Design: randomised controlled trial (Exanta Used to Lessen } \\
\text { Thrombosis A [EXULT A]). }\end{array}$ \\
\hline & Allocation: concealed. ${ }^{*}$ \\
\hline & $\begin{array}{l}\text { Blinding: blinded (clinicians, patients, \{data collectors, outcome } \\
\text { assessors, and data analysts\} } \dagger \text { ).* }\end{array}$ \\
\hline & Follow up period: $4-6$ weeks. \\
\hline & $\begin{array}{l}\text { Selting: } 116 \text { centres in the US, Canada, Israel, Mexico, and } \\
\text { Brazil. }\end{array}$ \\
\hline & $\begin{array}{l}\text { Patients: } 2301 \text { patients who were having primary total knee } \\
\text { replacement and weighed between } 40 \text { and } 136 \mathrm{~kg} \text {. Exclusion } \\
\text { criteria included pneumatic leg compression; immobilisation } \geqslant 3 \\
\text { days; major surgery, stroke, myocardial infarction, or receipt of } \\
\text { study drug } \leqslant 30 \text { days before surgery; increased risk of bleeding } \\
\leqslant 90 \text { days before surgery; increased risk of bleeding } \leqslant 90 \text { days } \\
\text { before surgery; uncontrolled hypertension; thrombocytopenia; } \\
\text { drug or alcohol abuse in the past } 6 \text { months; and potential for } \\
\text { pregnancy. }\end{array}$ \\
\hline & $\begin{array}{l}\text { Intervention: twice-daily tablets of ximelagatran (Exanta, } \\
\text { AstraZeneca), } 36 \mathrm{mg}(\mathrm{n}=775) ; 24 \mathrm{mg}(\mathrm{n}=762) \text {; or once daily } \\
\text { warfarin (Coumadin, Bristol-Myers Squibb) ( } \mathrm{n}=764) \text {. Placebos } \\
\text { were given for each study drug. Ximelagatran was started } \geqslant 12 \\
\text { hours after surgery when haemostasis had been achieved and } \\
\text { warfarin was started the evening of the day of surgery and } \\
\text { adjusted to achieve an international normalised ratio (INR) of } \\
2.5 \text {. }\end{array}$ \\
\hline $\begin{array}{lll}2 \\
2 \\
2\end{array}$ & $\begin{array}{l}\text { Outcomes: composite primary endpoint of total deep venous } \\
\text { thrombosis (DVT), pulmonary embolism (PE), and all cause } \\
\text { mortality during treatment (7-12 d); composite of proximal DVT, } \\
\mathrm{PE} \text {, and all cause mortality; and bleeding. }\end{array}$ \\
\hline$\Delta \square$ & $\begin{array}{l}\text { Patient follow up: } 2285 \text { patients (99\%) (mean age } 68 \text { y, } 62 \% \\
\text { women) were included in the safety analysis and } 1851(80.4 \%) \text { in } \\
\text { the efficacy analysis. }\end{array}$ \\
\hline & $\begin{array}{l}\text { *See glossary. } \\
\text { †Information provided by author. }\end{array}$ \\
\hline
\end{tabular}

\section{MAIN RESULTS}

Fewer patients who received ximelagatran, $36 \mathrm{mg}$, had an occurrence of the composite primary endpoint than did patients who received warfarin (table). The ximelagatran $24 \mathrm{mg}$ group did not differ from the warfarin group (table). Neither ximelagatran group differed from warfarin for the secondary composite endpoint of proximal DVT, PE, and all cause mortality ( $\mathrm{p}$ values $>0.10$ ). Groups did not differ for bleeding (table)

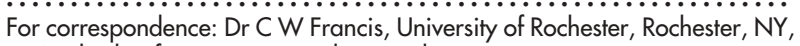
USA. charles_francis@urmc.rochester.edu

Source of funding: AstraZeneca.

\section{CONCLUSION}

In patients having total knee replacement, ximelagatran, $36 \mathrm{mg}$ twice daily, was more effective than warfarin in preventing venous thromboembolism.

\section{Abstract and commentary also appear in ACP Journal Club.}

\section{Commentary}

he trial by Francis et al shows the superiority of $36 \mathrm{mg}$ twice daily of ximelagatran over warfarin, both started after surgery, for prevention of VTE after total knee replacement surgery. However, as the greater efficacy came entirely from a decreased incidence of isolated (largely asymptomatic) calf vein thrombosis, the interpretation of these results deserves comment.

In most studies, comparing low molecular weight heparins (LMWHs), which have a rapid onset of action, and oral anticoagulants, which require 2-4 days to render an anticoagulant effect, the latter category of drugs has been less effective. Because both the study and the comparator drugs were started at the same time after surgery, I wonder whether the superiority of ximelagatran simply reflects the different onset of action of the 2 drugs. All that oral anticoagulants can do in this setting is prevent thrombus from growing. Indeed, both in this trial and in virtually all those assessing $\mathrm{LMWHs}$, the incidence of proximal vein thrombosis and that of $\mathrm{PE}$, when taken together, did not differ between patients receiving oral anticoagulants and those receiving heparin.

Despite this consideration, warfarin is problematic for VTE prophylaxis because of the need for laboratory monitoring and potential drug interactions, and $\mathrm{LMWHs}$ are the standard of care for the prevention of VTE after orthopaedic surgery. Although ximelagatran was shown to be more effective than enoxaparin in the EXPRESS study, it has not been compared with fondaparinux, a synthetic anti-Xa inhibitor that is more effective than enoxaparin for VTE prophylaxis after orthopaedic surgery. The ultimate comparison of efficacy in the prevention of VTE after orthopaedic surgery may be a head to head comparison between ximelagatran and fondaparinux.

Continued on next page.

Ximelagatran (X), $36 \mathrm{mg}$ or $24 \mathrm{mg}$ twice daily, $v$ warfarin after total knee replacement at 7-12 days*

\begin{tabular}{|c|c|c|c|c|}
\hline Outcomes & $X$ dose & Event rates & $\operatorname{RRR}(95 \% \mathrm{Cl})$ & NNT (Cl) \\
\hline \multirow{3}{*}{$\begin{array}{l}\text { Composite } \\
\text { primary } \\
\text { endpoint }\end{array}$} & $36 \mathrm{mg}$ & $20.3 \%$ v $27.6 \%$ & $\begin{array}{l}26 \% \\
(9.9 \text { to } 40)\end{array}$ & 14 (9 to 40$)$ \\
\hline & $24 \mathrm{mg}$ & $24.9 \%$ v $27.6 \%$ & $\begin{array}{l}9.8 \% \\
(-8.8 \text { to } 25)\end{array}$ & Not significant \\
\hline & & & RRI (CI) & NNH \\
\hline \multirow[t]{2}{*}{$\begin{array}{l}\text { Major } \\
\text { bleeding }\end{array}$} & $36 \mathrm{mg}$ & $0.8 \% \vee 0.7 \%$ & $\begin{array}{l}18 \% \\
(-61 \text { to } 264)\end{array}$ & Not significant \\
\hline & $24 \mathrm{mg}$ & $0.8 \% \vee 0.7 \%$ & $\begin{array}{l}20 \% \\
(-61 \text { to } 270)\end{array}$ & Not significant \\
\hline
\end{tabular}

${ }^{*}$ Composite primary endpoint $=$ venous thromboembolism, pulmonary embolism, and all cause mortality. Abbreviations defined in glossary; $\mathrm{NNT}$, NNH, and $\mathrm{Cl}$ calculated from data in article. 